The Institute has attempted to obtain the best original copy available for filming. Features of this copy which may be bibliographically unique. which may alter any of the images in the reproduction, or which may significantly change the usual method of filming, are checked below.

Coloured covers/

Couverture de couleur

Covers damaged/

Couverture endommagée

Covers restored and/or laminated/

Couverture restaurée et/ou pelliculée

Cover title missing/

Le titre de couverture manque

Coloured maps/

Cartes géographiques en couleur

Coloured ink (i.e. other than blue or black)/

Encre de couleur (i.e. autre que bleve ou noire)

Coloured plates and/or illustrations/

Planches et/ou illustrations en couleur

Bound with other material/

Relié avec d'autres documents

Tight binding may cause shadows or distortion along interior margin/

La reliure serrée peut causer de l'ombre ou de la distortion le long de la marge intérieure

Blank leaves added during restoration may appear within the text. Whenever possible, these have been omitted from filming/

Il se peut que certaines pages blanches ajoutées lors d'une restauration apparaissent dens le texte. mais, lorsque cela était possible, ces pages n'ont pas été filmées.

Additional comments:/

Commentaires supplémentaires:
L'Institut a microfilmé le meilleur exemplaire qu'il lui a été possible de se procurer. Les détails de cet exemplaire qui sont peut-être uniques du point de vue bibliographique, qui peuvent modifier une image reproduite, ou qui peuvent exiger une modification dans la méthnde norma!e de filmage sont indiqués ci-dessous.

Coloured pages/

Pages de couleur

Pages damaged/

Pages endommagées

Pages restored and/or laminiated/

Pages restaurées et/ou pelliculées

Pages discoloured, stained or foxed/

Pages décolorées, tachetées ou piquées

Pages detached/

Pages détachées

Showthrough/

Transparence

Quality of print varies/

Qualité inégale de l'impression

Includes supplementary material/

Comprend du matériel supplémentaire

Only edition available/

Seule édition disponible

Pages wholly or partially obscured by errata slips, tissues, etc., have been refilmed to ensure the best possible image/ Les pages totalement ou partiellement obscurcies par un feuillet d'errata, urie pelure, etc. ont été filmées à nouveau de façon à obtenir la meilleure image possible.

This item is filmed at the reduction ratio checked below/

Ce document est filmé au taux de réduction indiqué ci-dessous.

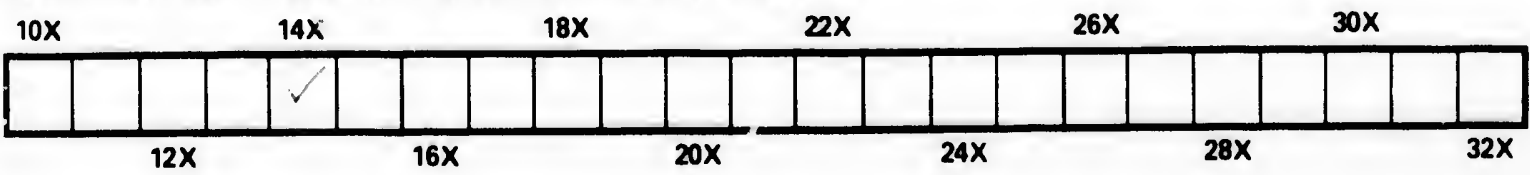


The copy filmed here has been reproduced thanks to the generosity of:

\section{Library of the Public Archives of Canade}

The images appearing here are the best quality pessibie considering the condition and legibllity of the original copy and in keeping with the filming contract specifications.

Original copies in printed paper covers are filmed beginning with the front cover and ending on the iast page with a printed or illustrated impression, or the back cover when appropriate. Ail other original copies are filmed beginning on the first page with a printed or illustrated impression, and ending on the last page with a printed or iliustrated impression.

The last recorded frame on each microfiche shail contain the symboi $\longrightarrow$ (meaning "CON. TINUED"), or the symbol $\nabla$ (maaning "END"), whichever applies.

Maps, plates, charts, etc., may be filmed at different reduction ratios. Those too large to be entirely included in one exposure are filmed beginning in the upper left hand corner, left to right and top to bottom, as many frames as required. The foilowing diagrems illustrete the mothod:

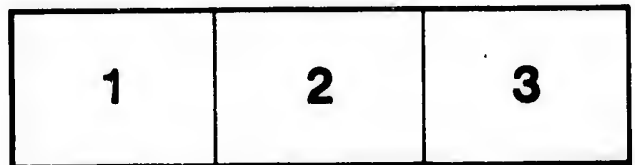

L'exempiaire fiimé fut reproduit grâce à is générosité de:

La bibliotheque des Archives publiques du Canada

Les images suivantes ont oté reproduites avec ie plus grand soin, compte tenu de la conditior et de le netteté de l'exemplaire filme, et en conformité avec les conditions du contrat de filmage.

Les exemplaires originaux dont la couverture en papier est imprimée sont filmés en commençant par le premier plat et en terminent soit par la derniere page qui comporte une empreinte d'impression ou d'illustration, solt par le second piat, selon le cas. Tous les autres exemplaires origineux sont filmes en commençent par la premiere page qui comporte une empreinte d'impression ou d'illustration et en terminant per la derniere page qui comporte une telle empreinte.

Un des symboles suivants appereîtra sur la dernidre imege de chaque microfiche, seion le cas: le symbole $\rightarrow$ signifie "A SUIVRE", le symboie $\nabla$ signifle "FIN".

Les cartes, planches, tableaux, etc., peuvent être flimes $a$ des teux de réduction différents.

Lorsque le document est trop grand pour être reproduit on un seul cliché, il est filmé à partir de i'angle supérieur geuche, de geuche à droite, et de haut en bas, en prenent ie nombre d'images nécessaire. Les diagrammes suivants iilustrent is mothode.

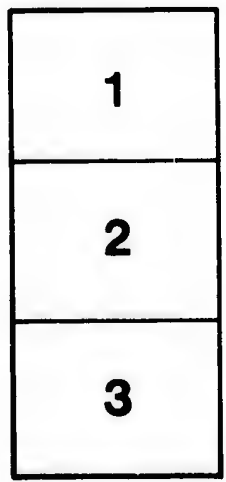

\begin{tabular}{|l|l|l|}
\hline 1 & 2 & 3 \\
\hline 4 & 5 & 6 \\
\hline
\end{tabular}




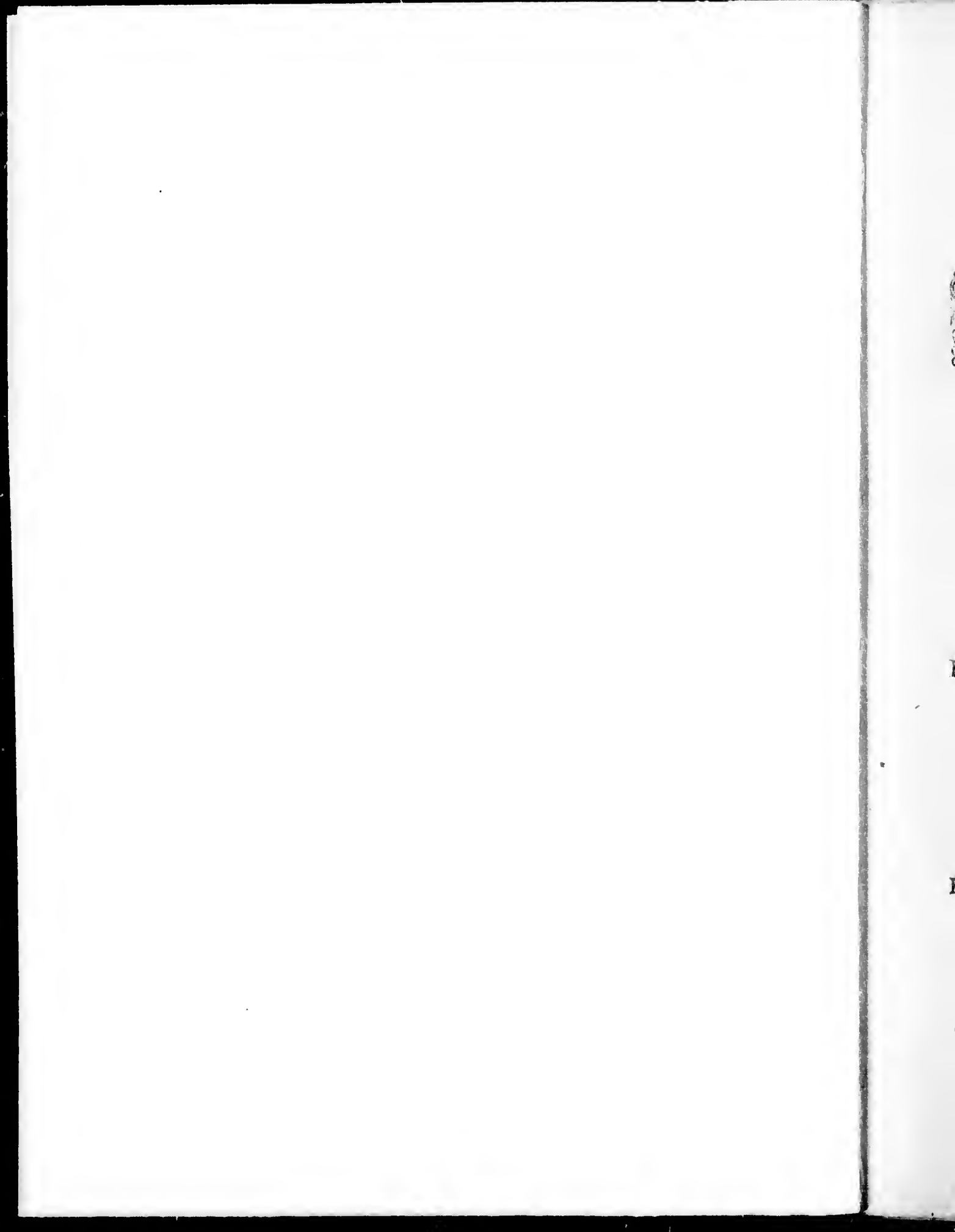




\section{LANDS AND RESOURCES 2.}

or
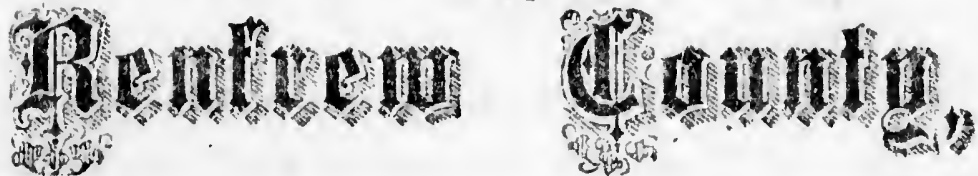

\section{PROVINCE OF ONTARIO.}

\section{A HAND-BOOK}

EOR THE MTORMATION OF MMMTGPAR' FARMERS DESTROTS OF OBTAININ CHEAP FARME IN AN ALREADY SWTTLED DISTRICT. \%

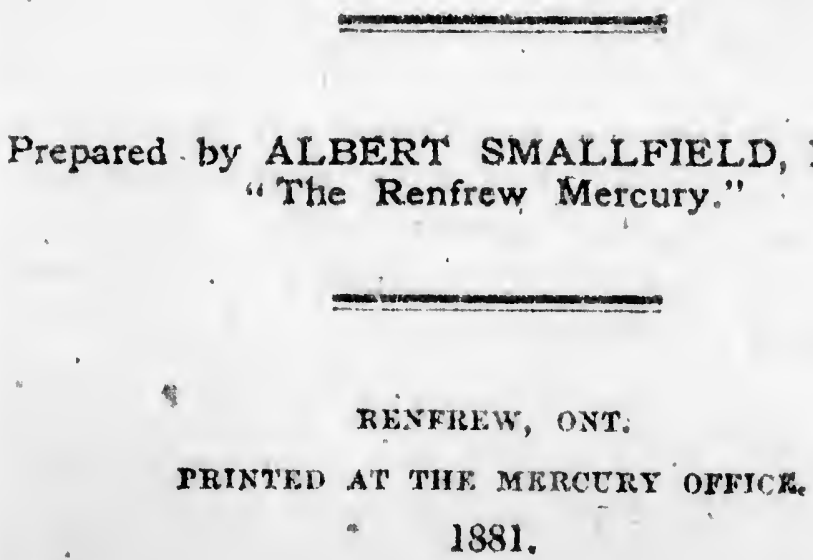




\section{INTRODUCTORY.}

TuF altention of Farmers and others who have none to Canada with the intention of purchasing land and setuling down to agrieultural pursuitswithout having definitely decided as to what nar. licular part of the Dominion they will select for their future residence-is directed to the following facts coneerning the County of Renfrew, it the Province of Ontario.

That has been lone, ean be done again, and ay there are many wealthy farmers already in tho rombry there is no reason why others-for whom there is plenty of room-with skill and capital, struld not equally well sueceed in securing an independence here.

Fis" Nueh information as to municipal institutions, echcational solvantages, \&ce, in-Canada, is already published in pamplets on immigration issued by the lominion and Pro. vincial Governments, which it is consequently not necessary to repeat in this brief sketcin. 


\section{RENFREW COUNTY :}

ITS J.ANDS AND RESOURCES.

$\mathrm{arO}$ ing sin$178 l^{\circ}$ for low ili id 3.4 the hom pital, git all

edirhed in Pro. cessary

"Tumbering" until recent years was the proir.ripal industry in the Comnty. As the forest. boldering on the riveria, bave gradually reredal further northwatd and westwarl befere the ham herman's axe, tho townships "in the front" have hesen converted into farms: and the lambermen' principal "limits" are mostly from 50 to aboyc lan miles bask into the interion.

'Thirby yeals ago, althourh thele were some on and fourishing settlements alomg the Otiaw: Wiver and tor some litte distance ny the Madab waska and Bonnechere Rivers, the interion of the (onnty was still compalatively an unsetled wi. formess, although squatlore here and there hat mato clearings and settements l'he immigration from Great Britain had been chiefly attracend ab ihe Western part of Upper Canadin, whore the land was more level, freer fiom lock, and the rat:mate somewhat milder. Settlement, at ths: nonol, in the central and castern parts of Uppe: cinada scarcely extended into the conntry nore than twenty miles north of Isike Ontario, and : has distance westerly from the Otrawa liver. In finct, the interion of the Provinces was goneral!y dectared and belicred to ba nufit for white mes. and of compe unsuitable for those acenstomed to the babits and tastes of a civilized community. It. was, in short, eontended that ali the good labid lad heen taken up, and that what remained Has intended by nature: for Indians and hunters-and 
Jambermen. Indeed, some louding inmbermen did not hesiate to assert that the soil would not rase sufticiont wheat to support a resident popu. lation. Novertheless, about thirty years ano, it hegan to be dectared that throughout the Hituron and Ontario district, as it was termed, there was much good hand, fit for sethement, which had only: been overtonked on aceount of the greater care with which the lands in the western part of the Prorince conld be reached. It was therefore pro. posed that this extensive distriet should be opened wp by the construction of soveral leading lines of "Colonization Roals."

the sehemo was ultimately adoptod, and Gorcomment Agents were apprinted to superintend the settement of the "Free Grants" which weres wifered to immigrants to induce them to sottle in the district.

These Agents soon put out glowing and attrative acconnts of the lands which they had to dis. fose of and how easily the immigrants could berome independent by the money which they cond make by clearing the band, and converting the Hees, whon felled ami burned in the log heap, into potash, for which, in those days, there was a ready ande for cash. While some of the Agents have contended that they stated nothing but facts. it is beyond dispute that the majority of the early rettlers who were induced to take up Jiee Grantis, found themsolses wofnlly disappointed,-there being the greatext possible difference between the promises and prospects held out and the reality. The roads were rough: it was toilsome and unaccustomed work to fell the trees and make the potash: there were no markets near at hand, and the cost of hauling the potash to the firont, and 
1011 $110 t$ pil). it roll wats $011 !$ (aise 110 ploilled os of

Gor -

tend 110?es le in

tital:0 dis(i) bocollit

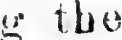
heat? was : unter facts. citl 1 ม"ล - 1 helec (en 1110 eality. nd $11 \mathrm{t}-$ ke the d, and int, and

of taking back plovisions, funiture, fie, soon crhansted the means of many of the settlers, who "ubandoned their "locations," and removed elsewhere, cursing thoso whose representations had fluded them. And theru are those who to this lay maintain that the Free Giants are, agricul. turally considered, of little worth, after the first cops have been taken oft?

That being tho case, it will naturally be askel why invile tho attention of immigrants to sisch il district?

Briclly, cireumstances have altered of late vans. The Opeongo Colonization Roal, which mins across Renfiew Connty fiom East to West. hats heen much improved, and appropriations of money have been made by tho Government of Dratro for still further improving it and the buach roads connecting with it. And in tho Histricts where at one time the settlers needed relief, the crops, in the year 1880, were splendid. illages and general stores in the back comntry have increased in number: and wherass the lum. herneri formorly afforded the only malliet for the settiers' surplus produce, the days for maline mash have woue by-and the setters hare foum arealy sale for their buter, while the comntry it seonroil avery seatson by the buyers of horser. rante and simep. As for the allegation that the (o) antry is mit for settlement, it is well known that the lumber kings, who were so ready to decry tho agricultuat capabilities of the district, ren"rally contrive to char a tolerably extensivespace tor a firm in the noighbourhood of their principa! "depots."

Miny of the early settlers, before the days of the Free Giants, not only found a marliet for 


\section{Renfrew County:}

their pooluco in the lomboring "shantics," but nsed to take their trams into the woods in thes winter timo, getting yaid tion hanling logs, and having theix horses well fed at the same time at the expense of their employers. 'This led to their. farms being neglected, and unfited the ownors for the steady wotk of the farm. Many farms, as well as supplies, were also obtained on eredit. This embarmassed the owners, and as tho lumbering districts receded, and the settlement of the Sorth- West territories offered inducements to ob. kin lands on easy terms, - many of the farms were sold in order to realize the means of settline aiber in Minnesota, or Dakota, or in Manitobie Hany atso passed into tho hands of the Joan Gompanies.

lint. firom one anse or another, there are still in the Counts of Renfrow, many farms-charod. saneed and with snitable buildings onecter--fon"

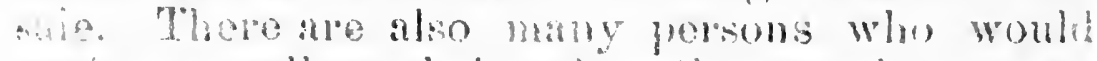

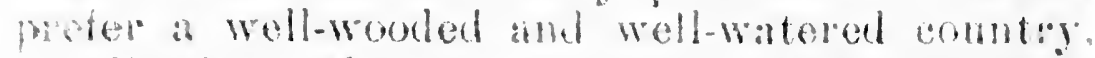

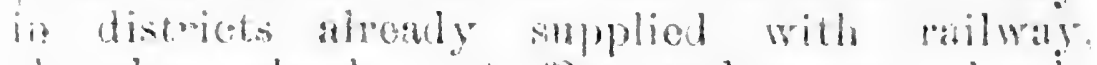
chatelues, schools, post ofticos and stores, amb only

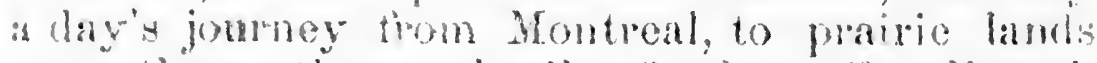
aroge than shousand miles further off. lispeci. aily when these chared farms, with all improve. recuts, can be purchasen outright for a sum pro.

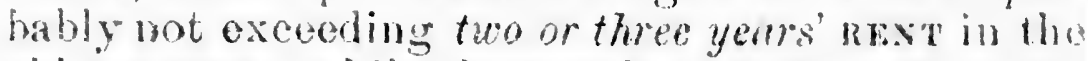
ald comentry: while the purchase is fiec from the rostly" chareres attending the conveyance of land in Enghand.

It is for the propose of atracting tho attention of immigrants of this class-men with some 3neans, aril not oblyed to "gongh" it in the lree frrants, - throt this lifle pamplifet is issued. 
bins

thes

sm.

10 al

their

vilors

1], is reriil. mberof the (i) obfaimis tilin:s itobar. Joidu

o still learor. $\left.\left(1-f_{i}\right)\right]^{\prime}$ woulis , matt:y, tilimaty (1) 13 landis Hispecimplove 3n prom rin the om) llis: f haud. tention: h some he free l.

\section{Area and Surface Features.}

The County of Renfrew is one of the Rurgest in the Province of Ontario (formerly styled Upper "unada or Canada West). It is silnated in the () tawa Valley, being bounded on the Fast and. Forth by the Ottawa (or Gand) River, $\mathrm{ly}$ which bis separated from the Western boundary of the Province of Quebee, formerly known as Jower cunada. On the South, it is bounded by the onntien of Lanark. Frontenac, and Addington; un the West by the Connty of Mastings; and on the North by tho Nipissing Distriet, throngh which the Western Fxtension of the Canada Centat Railway is now being built.

the area of the county of Renfrew comprises whut one million $(1,000,000)$ acros, -or neaty nethird the size of Yorkshire, the largest comby in Fingland.

\section{Rivers and Lakes.}

It is traversed from the North-west to the Southcast by the Rivers Madawaska and Bonnechere. which rise in the Nipissing District and fall into tho Ottawa River towards the southern limit of the County. In the Northern part, the Petewawa flows eastwadly also, but falls into the (otawa rome miles above Pembroke, the County town. There are some smaller streams, at the month of ono of which, the Muskiat, Pembroke is situated, (n) the Allumette Lake, an expansion of tho 1) tha River. None of these tributaries of the larger stream are navigable, except by small boats and canoes, being broken throughout their 
"onse by frequent rapids and falls, or "chuter;" which afford oxcellent mill-sites, with ample watep-power. These havo hitherto been chintly utilised for saw and grist mills; but at the Vil. lage of kenfrew there are several other lactories ahealy established at the falls of the bonnechere, and eforts are being mado to introduce ofhers. the streums are chietly used, however, for thoul. ing down the "lumber," which is ent down in the woods during the winter season.

'There are mumerons Lakes throteghont the county, some quite small, others soverial milus in lensth, mostly abounding in tish. In the noiginmoluthogd of Romnd Take and Cloar Lake, near ihe centre of the Combty, phosphate is being mined io comsiderahle quantity; and at Culabogive Take, in the southem part, inon, plumbago and nthor minerals, hate lately been discoverol, and the deposits ane reproded to be guito extensire.

\section{The Quality of the Land.}

tho land, in such an extensive tratet, is of come considerably diversified in quality, being i) somo parts heax $y$ elay, in others loam, and in ohors, sandy and barren. Thromghout the comb. 1y the surface is enerally billy; with a good deal if youk; and these hills, tomards the West, somsrimes rise info monntainous ridges. One ut these, known as The Pinnacle, is just North at 1/e Village of lienfrew. Although precipitous an its western face, it is cultivated in parts to its simmmit. Tho ridgo extends to the North for somo miles, and at its foot lies a fertile plain,"the Brule," and a fine stretch of the valley of the bonnechere. The rarying ralue of tho lasd; 
aceoding to soil, length of time it has been sot. thed, the consequent value of improvements, tho

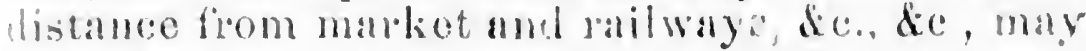
he judged frem the bast valuation put an the sov. exal Townships, tor the purpose of squahsing the mates for county taxalion, by the combly cona:... sil, in the your "1880:-

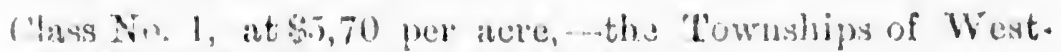
meath, Mesab, l'embroke and Horton.

('lass No 2 at $5.5,35$ per ace - the 'Lownship of Ross.

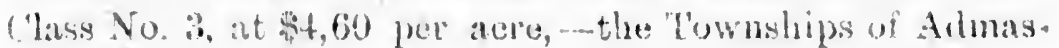
tunt, stafford, and Bromley.

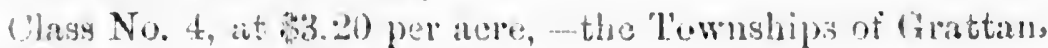
Wilberforce, and Alice.

Class No. 5, at $\$ 1,50$ per acre,-- the 'lown tips of Agona. Paint, Blythiehl, Brongham, Hagarty, sherwood, Richards. Junes, Bums, Butenell ani Lyudoch.

"Tass No. 6, at $\$ 1,30$ per acre - the Tuwnships of Griffith. latawachan, Hewl, Maria, Claril, L'etewawa, Rolph, Bi. hanan, Wylie, Selastopol, Rudelitip and Raglan.

Plie abose valuation 2 as nou of compe reprerout the real value the lamkls. It is merely an

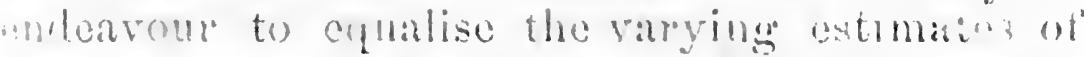

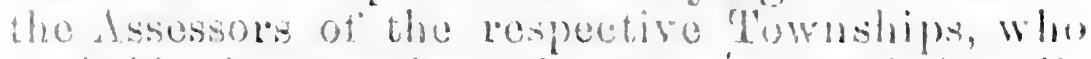
fubbably do not place the amonint on there rolls it mole than halt of the aletual ralue.

The following oxtracts from the surver of the Township of Raghan, which contalus an area ot"

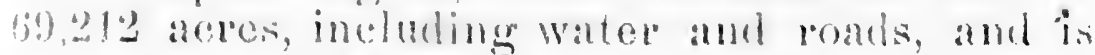
situated on the Western boundary of the Comn!y. maly be taken as a farir lepresentation of the arerage appoatance and quality of the land and the timber in the free Grant townhips:-

"The rocks belong to the Laurentian formation, aud con. sist for the most part of gneiss. In several places there are extensive exposures of white erystalline limestone, which snakcis a fair quality of lime, and may yet become of somes 
importance to settlers. No indications of valuable minerals were met with, and no specimens were collected.

"This township is well watered by streams, which abound in many kinds of fish. There are but two lakes of any conviderable extent, the largest being about a mile and a quarter in length and over half a mile in willth. Beaver meatows and ponds are to be found in nearly all parts of the township.

"The land in Raglan is mululating, or rollin;, and in many places is broken by swamps of cedar, spluce and tamarac, and by stecp rocky ridges, short and very irregular, and not inclined to any general course. The prevailing tinn. ber on those rough portions, and also along the Madawaska river, is pine. the best of which-through lumbering operatims, carried on for twenty years or npwards-has been removed, though a consirterable quantity of valuable timber still remains.

"In sereral places, once covered by beautiful groves of raluable pine, the tire has made a clean sweep of all vegeta. ison, or left only the diy trunks of trees.

"Throughont the township, except in the marshes and swamps, the soil. partikes of a sandy character, being in many places a deep rich sandy loam, which yields, where healings have been malle, whent, oats, corn, grass, and cereals of a very superiol character both in respect of yuality and quantity. 'In otler portions it is more saudy, especially' the level land along the Madawaska River, and many other. places where pine is the perailing timber, the land nay to classed as second rate.

"Where the limol is good the prevaling timber is beech, maple, and hasewood. The land in those portions corred by hardwoor is with some few exceptions favorable for agricintural purposes. In these exceptional places it becomes rough and rocky, and the timber is mostly maple, birch, ineeh, hemlock, pine, bilsam, oak, ironwood, elm, \&c. In the remaining portions of the township good land is only to be obtained in small patches, widely separated by spaces of rocky land and swamps."

\section{Agricultural and Horticultural Capabilities.}

While all the grain and root ceps cultivated in Circat Britain can be successfully raised in the Cumnty of Renfrew, other crops, such as Maize of 
minerals

$h$ abound any con. a quarter meardows fownship. , and in and taml. itregular, iling tini. rilawaska ng opera$s$ been re. le timber

groves of ill vegetiz. rshes and being in ds, where rass, and of puality especially any other ad may be. - is beech, is covered e for agrit becomes le, birch, 1, \&e. In is only to spaces of

\section{bilities.}

vated in 1 in tho Maize or
Indian corn, which rarely ripens in the Ola! country, and such vegetable fruits as melons, comatoes; de., which are there grown undor glass. sipen and yield abundantly in the open air.

The land which is not arable is well alapted to grataing and stock rasing, and this branch of arriculture is yearly increasing in importance.

Plams, cherries, rasplerries, gुooseberries, stawberries, grapes, tc., de., grow will. The rarden currant also grows to perfection; amb rapes and small fruits are also being cultivatod. Io meet the demand for apple and other fruit uees, suited to the climate, an extcusive nurery has, within the last fow yoars, been estahliohod near Aripprior.

Concerning the agriculural cambilities of this (a)unty we refer to extracts on parges 14 and 1. , ritien by a native of this section.

\section{Da:rying.}

Cheese Fateros aro being established in 110 "hunty: one at the village of Renfirw yelding a rar return to the shareholders.

Butcr is extonsirely exportol. From the Renrew station of the Camala Central latilway, 1.401) tubs were shipped in Oetober, and 2,285 in Nor"mber, 1880. One firm shipped tive car-loads direct to Liverpost. Another tirm shipped fiftecn ardoads. From the other stations lange quantilics were also exported.

BLE-KEEPING. - Ma?!y pritale individuala heep large mumbers of hives; and the climate is ivell-adapted to make the bnsiness quite profitable if followed more extonsirely. 


\section{Railways.}

The Canada Central Railway enters the Comb at Aruprior. Up till 1872, it terminated at Sanit Point, six miles north of Amprior. It was than extended to the Village of Renfrew, thirteen miles berond Sand Point; and three or four years afterwards to Pembroke, the County lown.

The Western Fixtension of the Canada Contral (to connect with the Canadian Pacific Railway) is now open to Doux Rivieres; will reach Mattawa in Inno of 1881 , and is expected to be comploterl as far as hake Nipissing by the eut of the rear.

The Kingston and Pembroke Railway-of which dio milos are built and being operated-will enter Renfrew Comby at the Madawaska liver, and will form a junction with the Canada Central at the Village of Rentrew.

\section{Towns and Villages.}

The principal places in tho County are

PEMBROKE, in the North eatern part, on tho Cipper Ottawa. It contains noarly 8.000 inhabi. lantis. There are sereral filctories, and a number of stores doing a large business.

IRNPRIOR is at the Southeas eorner of the comnty. 'A thir ides of the improvement which has of late gears taken place in the developmont of the County may he pleaned from the numerous the stores which have been erected; chief among

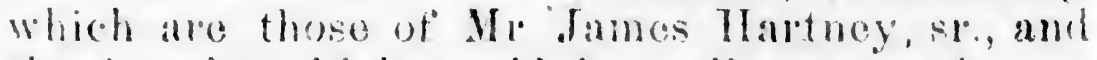
the Areade, which wombl do eredit to any sity.

RENEREN is situated on the Canada Central Ratilway, about half-way between Amprion and Pembrolie. It is the busmess centre of tho best 
agrieultural part of the County, and is the outlet if the Opeongo Rosd.

GGANVILLE is the next largest village. It is distant 26 miles from Pembroke, and the same iistance from Renfrew rillage. It is about 1: niles west of the Canada Central liailway, the weirest point being the station at

(COBDEN, where a considerable portion of the :Hricultura! produce of the district is now shipred.

The other villages are

SAND POINT, on the Ottawt TRiver and Canwha Central River, six miles from Arnprior.

BURNSTOWN, WHITE TAKW, and STEWARTVILLE, in the Township of McNab.

FORESTER'S FALLS, in Ross.

OSCWOLA, in the Township of Bromler.

DOUGI AS, about 16 miles from henfrew on the honnechere River.

BEACHBURG, in Westmeath, 15 miles from lembroke.

BRUDENELT, CORNERS, and TOOHINA: II II, in the 'lownship of Brudenell.

COMBERMERE, in tho Township of Radeliffe.

\section{High Schools.}

In addition to the Publis Schnols throughout the County, there are excellent IIigh Scbools for the more advanced branches of education at A.rnfurior, Pembroke and lienfrew; and the County Hodel School for training 'Teachers is established "the last named place. 


\section{"WHY CO WEST?}

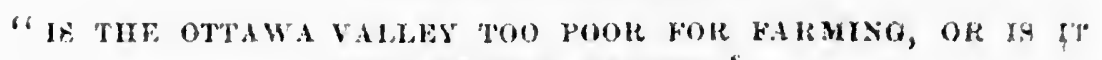
TOO ROORIS FAKMELI"

"Tu the kitor of the Renfiem Mercur"y.

"Sir,...the inclination of the minds of men, women and chillen is to dissatisfaction with their present situation-no matter unler what eircunstances - wealth, position, hap. piness - all that the miml cau grasp ; yet contentment doc.x not conse. The secret of happiness is contentment. This is moven by the fact that many of those persons who so re cently hive lofi this listrict for the far West, are stated to be aheady wishing enther to return, or else to go still further West: the emigration from Manitoha heing now as great as the immigration into that Province. The movenent wes!warl into the far great North. West shows the predominam inclination of the human mind. When wall this move. intent cease? Inducements of all kimls are held out to the people to 'move West.' 'The Dominion Government; in. terested parties.- Iand Gompanies - the Raitway Companies all alvertise, yes alvertise the great benetits to he revivel dy settentant in the firent lane fomb, or in the ivestern states af the 'ITinan.' The gtatements thus male appear to satisfy the riscontented ones in the eastern Provines-and cupceidly in this part of (Bntalio-and away they move accorlingly.

-Now, Sir, I maintain that the Ottawia conntry offery equal inducements with the much belauded West, to those? antually intending tio make their livisg by farming; and that all that is uecessary to bring a large immigration into this country is to point ont faily the anfantires offered by at woll-uonded and well-watered conntry, with the seenery beatifally diversitien by hills and valleys, in preference to the frairies-and marshes of the West. It cannot be de. nied that the majority of those who have lat this section for the West, were those who found themselves either finan. cially or domestically in positions out of which they wishod to extricate themselveg and hence the deterniuation ton conmence, as it is caller, "the worll anew." 'This, though to those who bave gone, may be a sufficient reason for tha sten they have taken, is no just cause to come to the conclu. sion that liastern Ontario is a place where the ordinarily prudent man-no matter of what trade or salling-camos live as well as in any other place on the face of the globe. 
$x, 9$

9I1 : timn-.. n, hal. it dous This is so $\mathrm{re}$. teed to further. reat as t wes! minant movis. to to the nt; in. npanies reriven $V$ estern joear to ex-amel nove atc-

ly offers to those g; and tion into fered by scenery rence: to ot be de. section er tinany wisherl lation to , thomgh in tor the e conclu rdinarily - camnot glube.

"And now a worl to our discontented farmers-kindly eneant, though possibly it mal not be received in the same sricit.

"Our farming population, ail through this County, is latgely male up of persons who have, in a greater or lexs degree, worked in the winter tine, at making or driving timber and logs: which in the earlier days of settlement was in firirly remunerative employmont. But this has causent them, undel a different state of affairs, to neglect the carre if their stock and the enltivation of their farms, for the more immediate gain derived from working in the shanties. An. ather mistake, of an injurious tendency so far as ultimate arosperity is concerned, is the fact that many formers oceny min which they attempt to cultivate with entirely msuitable erops: and dissatisfaction both with their land and their oecupation is the natural result. We have as gom sheat land in some sections of this connty as any to be forml in the Dorninion; white other localities are only tit for grax. ing. Bat what lo we iud? A farmer on kay 200 acres of band, cropping year after year a large part of his farm with all the valieties of grain usually grown,-beanse his neigh liwus do the same thing, -Whereas perhaps none of his liand is especially suited for the cops put in. Agrin, many of the farns are too small, or the owners have ton little capital for them to be protitably walked; or machinery is procured at siteat cost, which cannot be constantly employed so as to return a fair interest for the outlay. Nom, if canitalist were to secur large enough trates of land for the protitable use of the imploved machiursy now in fashion, cultivating cach prortion with the crog beat suited to it, and employing the men who now make nnly a poor living ont of their poor farns, both parties would be mutually. benetited, and much hand now lyiag waste might be utilized. Another mistake wande by many of our farmers is in allowing the low land to cmain undearch, while they derote all their tine to enitiating the high land. Properly drained, the swamplandy ale the bers.

"The introduction of new and inproved stack, and their Imoper care during the winter, are matters requiring more atention than they receive, if the pursuit of argiculture is to yield protitable returus.

"This is no fancy picture. The lave many gool farmery who by skill and attention to such points, and by sticking to their legitimate business of farming, are in independent 
rircumstances, and content with their situation in life and surrommlugs. Many of then have at differsut times visited the West, heing induced to do so by the representations of others, or lyy the reports printed and circulated by interested parties. What is the consequence? They return home ritisfied that this is just as gond a comutry, with an equally rood climate. and a sottled state of society : and they are not disposed to break up all their present associations, and Hy to the West-perhaps to be blown an aly in a whirlwind, -.not knowing where to locate to the most alvantage-or to yitch down hap hazard on the pearies, where as far as the ye can reach, nothing can be seen but the rast broad, level jilain touching the horizon."

“* * The present is a favourable time for trying the "xperiment of developing the resources of the country by hringing skilled agriculturists with sufficient capital to start with, into the conntry. Such at least is the honest opinion of cule anxious for our material

"Licniren, July 20, 188 )."

"YRograss."

\section{Acreage and Average Products.}

In the recently puhlisher Report of the Ontario Agricu! tural Conmission, the cleared area is set lown at 204,836 t acres. The encrage yicht of fall wheat is 17 l bnshels pel itce; spring whoat, 12 bush.; barley, hardiy any grown 19 hush.; oats, 25 bush. ; rye, 19 bush.; peas, 16 bush. arn (ittle grown) $25 \frac{1}{2}$ hush.; huckwheat, 24 bush.; pota toes, about 15.3 bush ; turnips, 3223 bush. ; other root crops 233 Lush ; hay, abont 1 tou per acre. A large proportion oi the cleared acreage is devuted to pasture, and rather les. than 1 of 1 per ceut. to orchards.

Abont twenty-four per cent. of the uncleared lands are re ported suitable for cultivation, if cleared.

Farms can be purchased at rates varying from 50 cents to $\$ 50$ per acre, according to the nature of the soil, the charac ter of the improvements, and the facilities for reaching is market. Farms con be rented at from $\$ 1$ to $\$ 1,50$ per acro. 


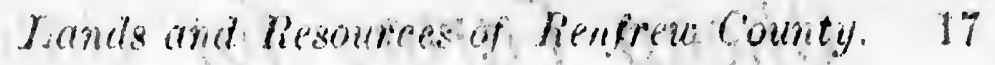

fe and visited ong of erested home equally bey are us, and lwind, e-or to as th. d, level ing $t$ th intry by to star opinion

RESS."

Agricnt 204,836 shels pes y grown is bush. 1. : pota oot crols: portion ather les:

ds are re

0 cents th he charac eaching is per acro.

\section{Climate.}

M.r T. H. Monk, of Toronto, a clerk in the Me recrological Service, in the employ of the Domi. nion Gorernment, when giving evidence betore the Ontrio Agricullmal Commission, in August, 1880. waid:-The climate of Ontario. Eenerally peaking is much intuchced by the vast bodies if water by whu it is party sirrommed. On

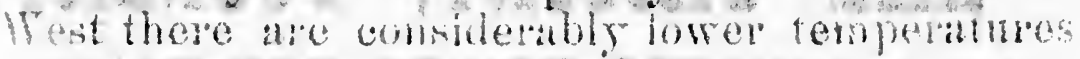

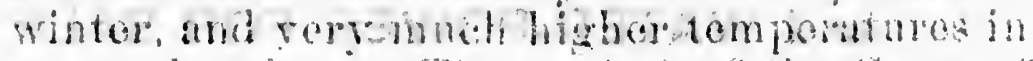
cummer that hose. The aritat of the state of jowa, for instance, has a rerg mold lower tempe-

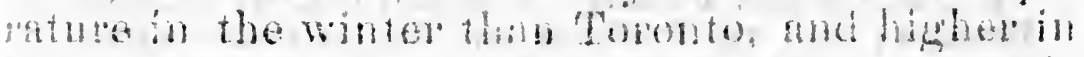

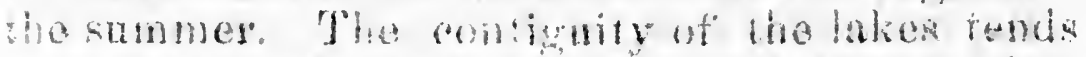

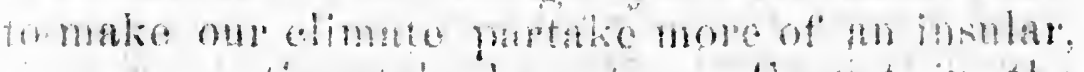

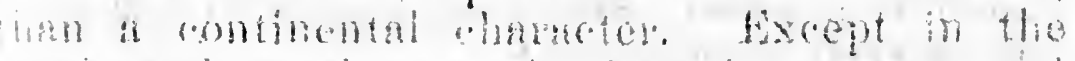

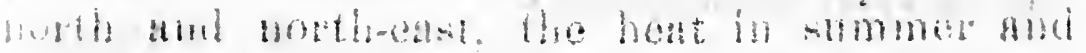

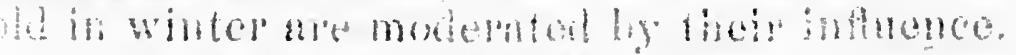

In the region af the Ottabit. The externes of mperame are much greater han at phaces in

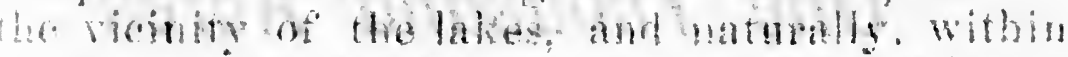

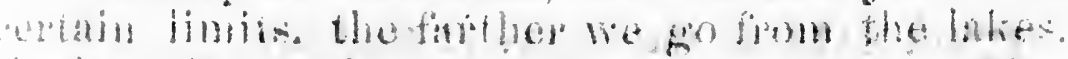
the bess their inthence is folt.

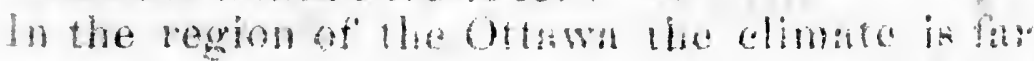
moge continental than in my ather pont of the

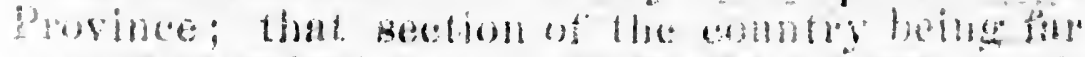
away from the hakes. the clinate is rem mueh the same as in some of the Wostert States.

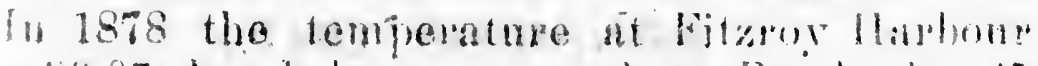

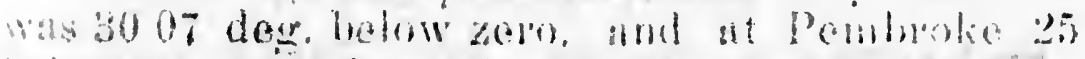

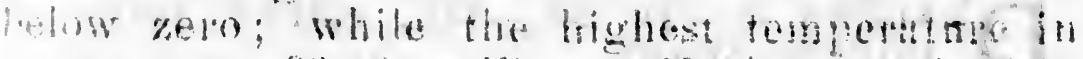

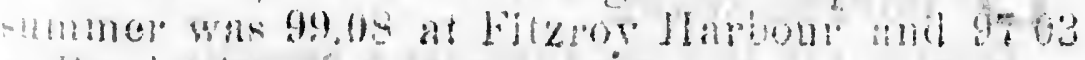
Perisbioke.

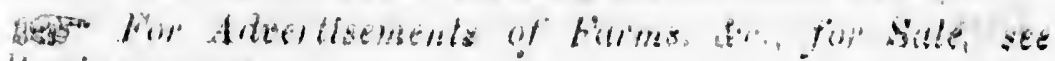
Wotcing pulyes. 


\section{Cheap Farms for Sale!}

A NUMBER of IMPROVED FARMS for Sale, Cherp: and upon easy terms of payment.

Apply to

JAHES BROMLEY.

RENFREW, ONTARIO.

\section{AXE FACTORY, FOUNDRY, and WATER.POWER FOR SALE.}

THE Undersigned ofiers for Sale his old-established Axe I Factory and Foindry, equipper with Trip-Hammer and Blowern; and the Premises and Water-Power attached, of the Bonnechere Falis, in the Village of Renfrew. A goon and improving business has baen done for many years, aud could be increased. Satisfactory reasons for selling. Fol terms, apply on the premines.

Y. MRANCIS.

\section{One Thousand Acres}

FOR SALE in the County of Renfrew.

Apply to JOHN SMITH, (Tanner),
ReNFew, ONTARio.

\section{TAYLOR \& ROBB, ARNPRIOR, ONT.,}

DEALERS in STOVES, TIN, SHEET IRON, and COPPER WARE.

Roofino and Hot-Air Furvaces a specialty. Furs.

Highest Price in Cash paid for Sheep Pelts, Calf Skins and 


\section{Small Farm for Sale!}

Clieris:

ARIO.

DART of Lot No. 14 in the lat Concession of the tunnship of HORTON. Containing 41 acres: shont 10 geres in soft wood bush. Frame Barn, 30xto feet. Hounded by the River Bonuechere and fenced. In the Village of Resfrew : one mile from the Post Oftice. For terms apply to

JOSHUA MURPHX,

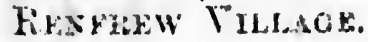

\section{Farms for Sale !}

1 MA ACREN-North. West Half of Lot 26 , Concession 11. IU) Township of MeNab, County of Renfrew. Soil, clay luam ; 40 acres cleared: snall orchard: goor log buildings; moperty near Sand Point.

7) ACRES-Lrit 21, Concession 8, Township of Fitzroy: w) Comnty of Carleton. Soil, day loan: 30 acres cleared; bog buildings; young rochard; two miles from Fitzoy Harbus, on the Ottawa River.

3 ACRES-mant of lot 2 in the listh Concesion, Town3) ship of MoNab. County of Renfrew, Soil. day loan;

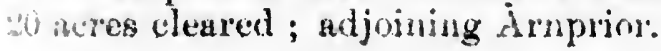

for particulars and prices apply to

), IARTO.

ON, and skins and

\section{F. A. BATES \\ ARXPKOLE OXTARLO.}

Oto A. I. CROSBY. 34 King St. East, Tonoxto, Oxr.

\section{Improved Farms for Sale!}

HMIGRANTS and others can be snited with Improved 1 Frarms at Low Prices and on very easy terms. For fur. ther information apply to

ADAM KENNEDY, PEMEKOKE, UXTAKIU.

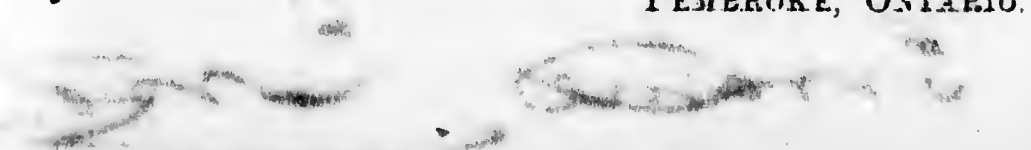




\section{FARMS FOR SALE!}

OEVERAL IMPROVED FARMS for sale in the 'I'own $\rightarrow$ ships of Grattan, Wilberforce and Bromley,-cheap, and upon easy terms of payment. Apply to

\section{JAMES REEVES, \\ Egavvilli, Oxtakio.}

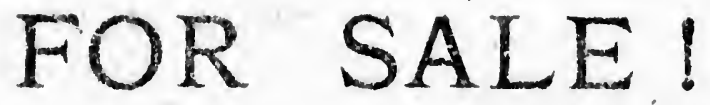

About 4,000 Acres of Land in the County of Renfrew.

Improved and Unimproved Farms In the Townships of MoNAB, ADMASTON, BROMLE? WILBERFURCL, \&

DOF PRCES LOW, AND TERMS LIBERAL,

\section{Also, MNNWG LANDS}

In the Conntieg of REXEREW, LANARK and LFEL

For Particulars addres

A. IV. BELI,

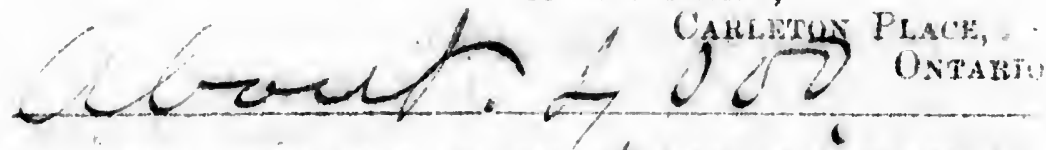

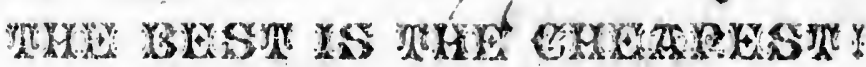

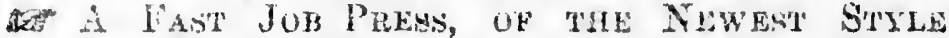
WTTH THE LATEST IMPROVkMENTS, and New Types, are being added to the Merougy Job-Printing Ofrice.

ERratgm. - In advertisement of "Farms fin Sale" preceding page, for "A. M. Crosby." read "A. M. CosnY.

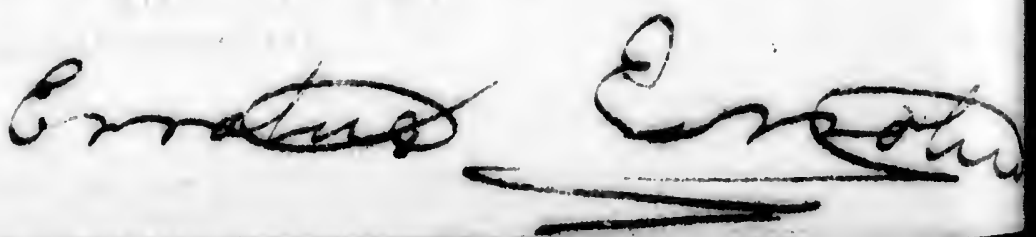




\section{Q1 \\ he Town. heap, nut




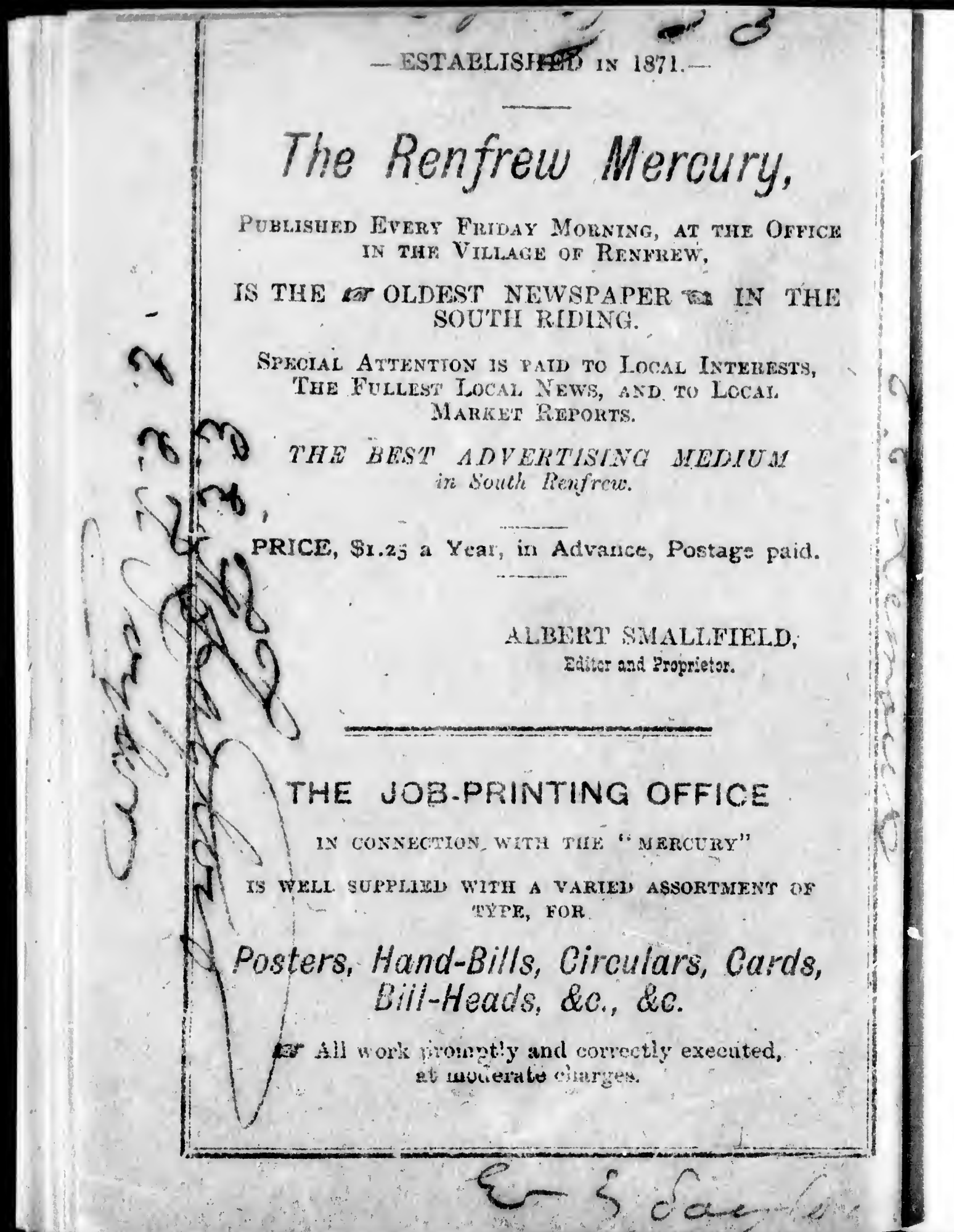


FICK

CHE

id.

(1)

$d s$ 


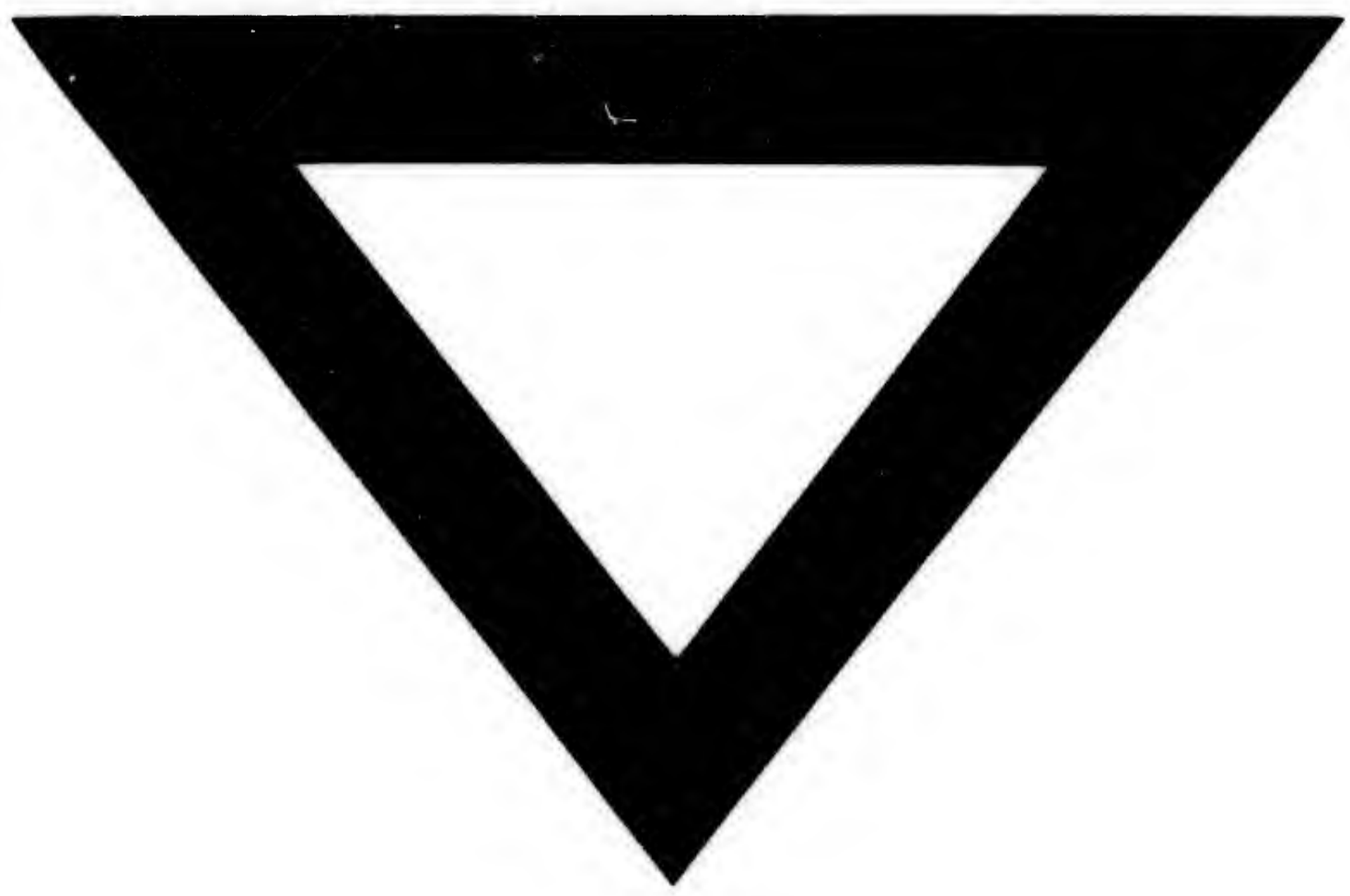

